\title{
How to Develop College Students' Autonomous English Learning Skills ---Take Reading Course in Joint-Program in HCFT as An Example
}

\author{
Jihui Wang \\ Department of International Trade and Economics, Henan College of Finance and Taxation \\ No.23, Nongye Road, Zhengzhou 450002, Henan Province, China \\ E-mail: zzuwjh@126.com
}

\begin{abstract}
The studies on autonomous learning based on the theories of constructivism and the advantages of technology propose valuable ideas for modern teaching theories and practices. In this paper, we put forward ways and methods in developing learner awareness, learning strategies and habits of autonomous learning in Henan College of Finance and Taxation (HCFT), taking English reading course as an example. The most significant findings are that in the model the guided experimentation promoted students' English language competence to a larger degree than that of traditional ways of learning, and that most of the experimental students became more active and positive in English language learning and eventually enjoyed the process.
\end{abstract}

Keywords: Joint-program college student, Autonomous English learning, Learning strategies

\section{Introduction}

When the question of foreign language teaching is discussed, some specific things come into focus. However, the primary issue should be the aim of foreign language teaching, which leads to other important issues such as what is taught and how it is to be taught. Holec (in Wan Li, 2006) claimed that the final aim of foreign language teaching is to awaken in students how to learn the language.

With the development of science and technology, there are some promises to foreign language learners. In current times, among them is the wide spread of computer science and Internet services, which could be used to facilitate foreign language teaching because they can expand course offerings in the campus.

In this paper, a model of computer-aided autonomous English language learning is proposed. The model is aimed at developing the joint-program college students' English language learning competence in HCFT.

\subsection{Research background}

In 1981, Holec Henry introduced the concept of "autonomous learning" in his book named Autonomy and Foreign language learning. After that, many scholars such as Lee (1998), Littlewood (2000), Gardner and Miller (2002) studied the issue and made greater contribution to the field.

In China, studies on autonomous English learning began in 1990s. From 2004, scholars who studied the issue from different perspectives have been making heated discussions on this topic:

(1) Studies on the strategies in autonomous English learning: O'Malley and Chamot (1990) studied the foreign language learning strategies; Wen (1995) studied the great importance of meta-cognitive learning strategies in learning a foreign language; Wan (2004) and Zhou (2005) studied the teaching and learning strategies in calling for and conducting autonomous English learning.

(2) Studies on the application of computers and Internet learning sources: Li (2005) discussed the possibilities and roles of the computer and multi-media in autonomous English learning; As a matter of fact, computer-aided autonomous English language learning was widely considered as a worthy model for Chinese college English teaching and learning since there are so many college students, who traditionally learn English in a big class with low learning efficiency level.

\subsection{The significance of the study}

The joint program referred to here is that between Henan College of Finance and Taxation (HCFT) and Victoria University. The problem with these first-year students was that the joint program students' English scores and English competence were under the average standard for college students when they were admitted into this college in 2008, with their total scores in the college entrance examination were 40-50 lower than other college students.

Another challenge was that these students had only one year to have English language courses due to the joint program curriculum, while the requirement of their college learning was much higher than that of other college 
students in China since two years later they would go abroad to Australia to study for their bachelor' degree.

In order to narrow the gap between the college curriculum aims and the challenges posed by the college students' English levels, experiments in developing autonomous learning style were conducted, taking into account the advantages offered by information technology.

\subsection{The research purposes and questions}

It is hoped that the teaching experiments can offer more exposure time and opportunities to communicate, diversity of materials and varied approaches to providing better conditions for learners to reach higher language achievement.

In our teaching and learning experiments during the year, the research questions were:

(1) With the same teaching and learning time but different teaching and learning models used by the experimental group and the parallel group, which group would achieve more in English language learning and using?

(2) What were the future benefits the experimental students would get from the new learning model?

\subsection{The research methodology and the theoretical framework}

\subsubsection{The research methodology}

This paper is going to adopt the documentation and experiment methodology. By case study as well as by way of description and the statistical analysis the focused points and questions were to be discussed and answered.

\subsubsection{The theoretical framework}

\subsubsection{Constructivist Teaching}

Constructivism is a philosophical orientation in teaching theories. Henson (2004) and David et al. (2009) suggested that learning does not occur simply by the brain taking a "picture" of something and filing it away somewhere in the brain to be retrieved later. Rather, learning is constructed by the brain as it seeks to relate new knowledge to prior knowledge. Therefore, each student will have a unique construction.

\subsubsection{Autonomous-learning}

Autonomous-learning is a modern learning theory based on the theory of constructivism. It is also a student-focused learning model which emphasizes the learning environment and cooperative learning. Autonomous learning was first developed by Holec (1981), which means that students take charge of their own learning by carrying out their own learning plans according to their own needs.

\subsubsection{Cooperative learning theory}

Cooperative learning theory was developed in America in the 1970s as a teaching theory and strategy system. It is a learning process based on groups and peer help to achieve learning goals. Studies (Deutsch, 1962; Johnson \& Johnson, 1989) showed that in cooperative learning situations there is a positive interdependence among students' goal attainments; students perceive that they can reach their learning goals if and only if the other students in the learning group also reach their goals.

\subsubsection{Information technology applied in education}

Online education is now an established phenomenon and a growing industry. According to Duval (2000), at least 1.5 million Internet courses were available through 3,000 different institutions in 1999. Clark (1999) reports that, by 1999 , two-thirds of accredited 4-year and graduate universities in the U.S. offered courses via the Internet.

\section{Developing students' computer-aided autonomous English language learning skills}

\subsection{The design of the experiments}

\subsubsection{The concept of "Autonomous learning" in this case}

By computer-aided autonomous English language learning, we mean students learn and practice English language not only in classrooms but also in computer-rooms using materials on Internet, learning discs and other electronic learning tools.

In order to facilitate and motivate students in the process, experiments on the students especially in improving students' learning competence such as making weekly learning plan, cooperative learning were conducted in the teaching and learning process. At the same time, by means of statistical analysis, students' English language scores in examinations were analyzed to find out the advancement of the students' English language competence during the process and the relationship between the students' autonomous learning effect. 


\subsubsection{The subjects}

The students were from four teaching classes: two classes (Group A, 64 students) were involved in the experiments while the other two classes (Group B, 62 students) were taught in a traditional way. The teaching material was those already designated by the faculty to teach these students.

\subsubsection{Data analysis}

Statistically, an independent sample t-test compares the difference between two means of two independent groups of participants to determine whether that difference is statistically significant.

In our research, the two groups were compared on the outcome of the first semester's study. The students' English scores of Group A and B in the examinations during the process were compared twice by statistical method using t-tests. The second comparison was based on the fact that the two groups were at the same level statistically in their English competence when they were admitted to the college as joint-program students.

The effectiveness of the students' autonomous learning such as the English scores and the effect on the students' perception about learning and using English in autonomous learning was analyzed statistically within the experimental group, by interviews and the answers to the two questionnaires.

\subsection{Conducting the autonomous English learning experiments}

\subsubsection{Teacher training}

In order to prepare for the autonomous English learning model, teacher training in the joint program of HCFT was carried out. As Shechtman et al. (2005) claim there are some important beliefs that influence the teacher perceptions and behavior, which includes:

"(1) All teachers must be lifelong learners;"

"(2) All students are worthy individuals;"

"(3) All students are able to succeed, and teachers can ensure that they do";

"(4) Lessons should encourage learners to become actively involved in creating their own knowledge."

Gardner and Miller (2002) also argued that in autonomous learning "teachers need to relinquish some of their control over learners" and "teachers need to learn new skills to take on their new roles". All the teachers came to understood that students are individuals who need to be treated with dignity and respect and teachers must understand and respond to students' differences in helping everyone grow in autonomous English learning skills and habits.

Shu (2006) argued that teacher's role can be described as "source of expertise, managing roles, source of advice, and facilitator of learning sharing roles, classroom atmosphere creator, evaluator, and example of behavior". Therefore, what our teachers did in the experiments was "active teaching", which was quite different from traditional teaching attitudes and strategies.

2.2.2 Getting to know the students and the design of the teaching experiments

For HCFT college students who study in the Sino-Australia Cooperative College Program, understanding their English language level and their learning styles was very important with the development of online teaching methodologies and the requirements of the transnational curriculum because these students were different from most of the other college students in China. 2.2.2.1 Pre-test

Before conducting the experiments, the two groups (A and B) were tested in English listening, reading and writing, using the same papers. The analysis of the students' scores was as follows in Table 1, taking English reading marks as an example.

The decision rule of the t-test is as follows: If the significance value (Sig. 2 -tailed) is less than alpha $=0.05$, it is reported that there is a significant difference between results of the two groups; if it's greater than alpha $=0.05$, then there is no significant difference between the two groups. By analyzing the marks of the students in 1 reading using SPSS Statistics software, it was found that, statistically, the two groups were at the same English reading level.

The above data identified the scientific basis for the following experiments. Due to the homogeneity of the two groups, we designed the following experiments. We chose Group A (64 students divided into two teaching classes) as the experimental group to develop their autonomous learning habits, while Group B (62 students divided into two classes) was taught in a traditional way in the first year. It was anticipated that by the end of the first year English learning, students in Group A would be used to the autonomous learning approach and demonstrate benefits from the process. 


\subsubsection{Pre-interview}

Experimental students were interviewed to determine their existing learning style and attitude. The interview was considered helpful to the future teaching and learning strategies. The questions asked are as follows:

(1)What do you feel and think about your middle school English learning?

(2) Are you interested and active in learning English?

(3) Do you plan your English learning activities in your college?

(4) Do you reflect and evaluate your English learning?

(5)How do you motivate yourself to study English hard?

(6)What are your important English learning strategies?

(7) Are your English learning strategies now the same as that in your middle school?

(8)What are your expectations in college English learning?

It was noticed that most students stated that they were inactive in their English learning activities, mainly focusing on the exams and memorizing the language materials. Besides, most of the students still adopted the learning strategy used in middle school and had little idea of how to plan their English learning, and even less of how to reflect on their own learning process. Also, many students were not satisfied with their English language competence especially with their communicating ability and all of the students were looking forward to a better mode of learning English language in the college.

2.2.3 Organizing teaching content

\subsubsection{About classroom learning materials}

First, the text books used in classroom teaching was New Horizon College English (2nd ed.), the famous college text-books in China for its very good content in English knowledge and skill practicing.

However, according to Cai (2001), 91\% of students think that it is not necessary for college teachers to deal with the vocabulary, language points and text analysis since the learning-assistant discs can offer all of the details for them. Therefore, in our experiments, teachers' job was mainly to introduce the topic of each unit and direct students to explore the background knowledge and to design appropriate learning tasks. For example, the reading texts in the first unit in the reading text-book are Learning a Foreign Language and Keys to Successful Online Learning.

\subsubsection{About computer-room learning materials}

Joint-program teachers spend more time planning lessons than they had done in traditional teaching activities. They carefully reviewed Websites and previewed software they want learners to use to ensure an appropriate fit with their lesson objectives.

The web-sites teacher chose for students were:

(1) About computer knowledge and skills: www.ask.com/, www.ajkids.com/, www.encarta.msn.com/, www.google.com, www.about.com/,and www.demoz.org/.

(2) About English language:

http://languagetrade.com,

http://how-tolearn-any-language.com/e/index.html,www.yeword.net/, http://www.mylanguageeexchange.com/,www.learningenglish.org.uk/,www.chompchomp.com/,

www.hua.umf.maine.edu/,www.chinatoday.com/, www.index-china.com/,www.chaos.umd.edu/, and www.art-bin.com/, www.chinavista.com/

(3) About culture: http://69.93.14.237/index.cfm, http://spankmag.com/(Worldwide site focusing on youth issues).

(4) About dictionary: www.dictionaries.com/, www.rootsweb.com/.

\subsubsection{About after-class learning materials}

Teachers offered students learning materials for the experimental students to use in case they could not get access to the most suitable ones on their own. These materials included short stories, newspaper and magazine articles, letters, Internet articles and English test materials for them to read and test their comprehension in their autonomous learning. The principle in selecting the learning materials should be interesting, readable, informative, and major-relative. 


\subsubsection{Motivating students}

Learner's motivation is one of the internal factors which affect the learner's performance. Studies (Spratt et al., 2003) suggest that autonomous learning is closely related to learner's motivation. In order to motivate students, measures were taken to build students awareness about autonomous learning and to develop students' autonomous learning habits. The theories of autonomous learning are introduced in class by the teachers explaining its significance and advantages to college English learning. The students' interests in the new way of learning were stimulated by being shown that they can adjust their learning speed according to their English level and can enjoy more freedom in the learning process. Teachers also answered students' questions and received feedback via Internet services, such as e-mail, groove and BBS. Teachers gave different advice to individual students according to different needs and hopes, which helped to build a good relationship between teachers and students.

Dynamic assessment also plays an important role in strengthening students' motivation when students' cognitive ability got developed and their autonomous learning ability was fostered. It will be described in details in part 2.2.9 about assessing students.

\subsubsection{Developing students' autonomous learning skills in their learning process}

\subsubsection{About computer-using skills and computer-rooms learning opportunity}

Students' were trained on computer using skills both in English and Chinese to facilitate their language skills by using Internet or other learning tools.

In the first semester, the teaching time of all the Group A students was 8 periods every week in classrooms with another 2 hours for autonomous English learning in computer rooms, while Group B enjoyed the same time of learning but learned in traditional way. During this semester, students were expected to get used to the autonomous learning process.

\subsubsection{Teaching of autonomous learning strategies}

According to O'Malley and Chamot (1990), autonomous learning strategies can be divided into "Meta-cognitive strategies", "Cognitive strategies" and "Social Mediation". These strategies are closely related to the motivation and learning efficiency of the learners. It has also been found that the more skillful students are at using learning strategies, the more successful their learning process is (Wen, 1995). Therefore, experimental students were taught these three kinds of learning strategies as follows.

(A) Cognitive strategies: analyses reading, association memorizing, note-taking and question-raising.

(B) Meta-cognitive strategies: study-planning, data-collecting, as well as self-supervising, self-evaluating, learning-reflecting, and personal file-making.

(C) Social Mediation: becoming relaxed in activities, making group rules, cooperating with partners, communicating effectively and evaluating peers' work.

Students were also required to apply their knowledge to their daily English learning activities, such as making learning plan, learning log, carrying out cooperative learning, etc.

2.2.6 Helping students in weekly learning plan and learning log

Every week, students were asked and helped to make a weekly plan and a weekly learning log of their English study including listening, speaking, reading and writing. Learning plans were made to guide their everyday learning activities. For example, students might put aside 30-50 minutes for listening and another 30-50 minutes for speaking. They might read a 500-700 word article and write anything they like about it in 50-100 words. At the same time, 2-4 hours of supervised computer-aided learning were offered to the students to support their plan.

The learning plan of each student was checked by her/his learning partners and teachers. The advancement of the student could be found by comparing the plans in the following weeks and then was considered as one of the aspects for the assessment outcome at the end of the semester.

The differences between each student's weekly learning logs and her/his learning plans in the same week could suggest whether the student's learning performance was satisfactory and whether the next week's learning plan should be changed. For example, about learning duration, learning materials and learning style, etc. Also, student's learning log can help every student learn to reflect on her/his study in the past week, which is an important aspect in autonomous English learning.

2.2.7 Cooperative learning.

Ellis (1994) argued that everything that occurs in the classroom goes through a process of live person-to-person 
interaction. A cooperative learning model was introduced into the classroom activities. In cooperative learning, learning processes were highlighted more than the outcome of the activity itself. Teachers organized the activities by giving certain tasks, encouraging students to explore the relevant information, cooperate with each other to fulfill the learning tasks and providing positive evaluation of the students' performances. Specifically, students in Group A were divided into several study teams, which consisted of 3-5 students with different English language levels and different learning habits. They worked together to help each other and learn from each other in the learning activities.

In English reading course, most of the tasks were reading comprehension and explanation. Students in groups were given questions and required to give their own answers and then the group answer. Students could also be asked to cooperate to write a summary of an article or give a presentation on a certain topic. Each of the team members would act as team leader, Master of ceremonies, secretary or recorder in different occasions to experience different roles in the activities.

In cooperative learning, teachers and students worked in an equal and friendly atmosphere, being a participant or a helper during the learning process. According to the feedback from all the students of Group A, most students enjoyed cooperative learning, reporting that they feel more relaxed and active in the job.

\section{Outcomes and findings of the teaching experiments}

\subsection{Scores Comparing between Group A and B and analysis of them.}

At the end of the first semester and the second semester, all the first-year joint-program students took the final examination in English reading course using the same papers. Score compared were conducted in reading scores, which was the most objective comparison among scores, between Group A and B were showed in table 2.

\section{2 post-questionnaire and the analysis of them.}

At the end of the first semester, we examined the development of the students' autonomous learning by means of a multiple choice questionnaire to be answered by all the experimental students. These questions were:

(1) Are there differences between your learning style in college and that in middle school?

(2) Are you trying to find some new methods and effective ways for learning English?

(3) Are you trying to learn English by all means in your spare time?

(4) Do you know a lot about independent learning?

(5) Are you interested in the idea of a computer-aided independent English learning program, which is offered in our campus?

(6) Do you like to learn English on a computer?

(7) In your opinion, does computer-aided English learning help with your creativity, communication ability, etc?

(8) Do you need partners to work with in computer-aided learning autonomous activities?

The possible answers to the questions were "Yes, I quite agree" (A), "may be I agree" (B), and "No, I don't agree" (C). Table 5 summarizes the student responses.

It was found that the majority of the students in Group A experienced the changes in the new college English learning model after three months training. Specifically, $94 \%$ of the students were trying the new strategies in their autonomous English learning; 38\% of the students kept learning English by all means in their spare time; $19 \%$ of the students had a lot of positive experiences in autonomous English learning, while $58 \%$ of the students could accept autonomous English learning anyway. Sixty-seven percent of the students were becoming quite interested in computer-aided autonomous learning style, while $42 \%$ of them could get used to it. Fifty-nine percent of the students enjoyed learning English using the internet, while $41 \%$ of them accepted that to some degree. In particular, $48 \%$ of the students thought the autonomous learning model could be quite helpful to their creativity power and social communicative ability, while $44 \%$ of them agreed with that. As to the needs of cooperative partners, $73 \%$ of the students felt they needed partners very often, while $22 \%$ of them agreed to have partners and became involved in cooperative learning activities, which suggested that they were getting used to the new learning style, generally speaking.

Other answers to the questions also suggested that the majority of the students thought computer-aided learning was helpful to their classroom learning and they believed that their listening and reading competence were greatly improved during the process. For example, in the aspect of making their learning plan, $40 \%$ ( 25 students) learned to make their learning plan according to their learning level and special needs, with $36 \%$ (23 students) of the students could do that to a certain degree. See table 3. 


\subsection{Answers to the research questions in this paper}

According to above mentioned data, the answers to the research question (1), (2) and (3) are:

(1) According examination scores comparisons, it was found that with the same teaching and learning time but different teaching and models used by the experimental group and the parallel group, the experimental group achieved more in English language learning.

(2) The experimental students (in Group A) felt quite positive about computer-aided autonomous English language learning and got more motivated during the first year. After the students found that they had learned a lot they eventually became proactive not only during the process but also in the future English learning.

\section{Conclusion}

The computer-aided autonomous English learning model benefited the experimental students (Group A) since they had improved more greatly than other students, who had been taught in traditional way. Besides, the teaching experiments promoted the students English learning attitudes and competence, which would help in future English learning and studying abroad.

It is expected that the students' positive attitudes towards language learning and their autonomy in learning would lead students to bigger success in the long run and even to their future career. It is strongly hoped that the experiments of autonomous learning in HCFT can be of broad significance to the Chinese college English education system and Sino-foreign joint-program teaching model in improving the teaching effectiveness and fulfilling the final aim of world-wide higher education.

\section{Acknowledgements}

The research is part of the Sino-Australia international program sponsored by Victoria University in Melbourne. The author would like to thank Fiona Henderson and Deng Li for their encouragement and editorial assistance.

\section{References}

Armstrong D.G., Henson K.T. \& Savage T.V. (2009). Teaching Today: An introduction to education (8th ed.).Beijing: China Renmin University Press.

Biggs, J. (1999). Teaching for Quality Learning at University, Buckingham: SRHE and Open University Press.

Ca,i Jigang. (2001). A new model of college English intensive reading. Foreign Language World (5): 73-77.

Clarke, R. D. (1999). Going the Distance, Black Enterprise Journal. 29 (9), 113-118.

De Garmo, C. (1903). Interest in education: The doctrine of interest and its concrete applications. New York: Macmillan.

Deutsch M. (1962). Cooperation and trust: Some theoretical notes. In: M.R. Jones (ed.), Nebraska symposium on motivation. pp. 275-319. Lincoln, NE: University of Nebraska Press.

Duval, M. (2000). Start-up plans in education market place. Interactive Week, 7, 35

Ellis, R. (1994). The Study of Second Language Acquisition, Oxford: OUP.

Gao, Jili. (2005). The studies on autonomous learning in China. Foreign Language World (6): 55-60.

Li, Zhiqiang. (2005). Computer-aided autonomous language learning. Nanchang: Jiangxi Normal University Press.

Gardner D. \& Miller L. (2002). Establishing Self-access: From theory to practice. Shanghai: Shanghai Foreign Language Education Press.

Henson, K. T. (2004). Constructivist Teaching Strategies for Diverse Middle-level Classrooms, Boston: Allyn and Bacon.

Holec, H. (1981). Autonomy and Foreign Language Learning, Oxford: Pergamon Press.

Johnson, D.W. \& Johnson, R.T. (1989). Cooperation and Competition: Theory and research. Edina, MN: Interaction Book Company.

Johnson, D. W., Johnson, R. T. \& Holubec, E. J. (1993). Cooperation in the Classroom (6th ed.). Edina, MN: Interaction Book Company.

Lee, I. (1998). Supporting greater autonomy in language learning. ELT Journal, 52(4), 282-291.

Liang, Pengcheng. (2004). The analysis of Teacher's discourse in developing college students' English autonomous learning. Nanjing: Nangjing Normal University Press.

Littlewood, W. (2000). Do Asian students really want to listen and obey? ELT Journal, 54(1), 31-36 
Millis, B. J. \& Philip, G. C. (1997). Cooperative Learning for Higher Education, Phoenix: American Council on Education/Oryx Press Series on Higher Education.

O’Malley, J. M. \& Chamot, A.U. (1990), Learning Strategies in Second Language Acquisition. Cambridge: Cambridge University Press.

Shechtman, Z., Levy, M., \& Leichtentritt, J. (2005). Impact of life skills training on teacher's perceived environment and self -efficacy. Journal of Educational Research, 98(3), 144-152

Shu, Dingfang. (2006). On the new model of foreign language classroom teaching. Foreign Language World (4): 21-29.

Spratt M., Humphreys, G. \& Chan, V. (2003). Autonomy and motivation: which comes first? Language Teaching Research, 6 (3), 245-266

Stiggins, R. J. (1997). Student-centered Classroom Assessment, (2th ed.) Upper Saddle River, NJ: Merrill.

Stiggins, R. J., Arter, J. A., Chappuis J. \& Chappuis, S. (2004). Classroom Assessment and Student's Learning. Poland, OR: Assessment Training Institute, Inc.

Tan, Jinghua. (2002). Forum on Educational Technology. Shanghai: Shanghai Foreign Language Education Press.

Wan, Hong. (2004). Studies on the Training of College Students' Autonomous English Learning Strategies.Chongqing: Southwest China Normal University Press.

Wan, Li. (2006). Autonomous learning in foreign language teaching. Education and Vocation (33):94.

Wang Tan. (2002). The Basic Concept of Cooperative Learning. Education Study (2):68-72.

Wen Qiufang. (1995). Different learning strategies between successful learners and unsuccessful learners. Foreign Language Teaching and Research (3):63-66.

Zhao, H. Q. (2008).Using the Internet to improve EFL for communicative purposes through reading and writing in China, POLYGLOSSIA, Vol. 14.

Zhou, Zhiming. (2009). On the teacher's new role in Internet learning context, from: [Online] Available: http://www.nctvu.cn/xueshu/7.htm. (5 July, 2009).

Table 1. Marks comparison between Group A and B in the first test given in October, 2008

\begin{tabular}{|l|l|l|l|l|l|l|l|l|}
\hline $\begin{array}{l}\text { Course } \\
\text { Scores }\end{array}$ & Group & Cases & Mean & $\begin{array}{l}\text { Standard } \\
\text { Deviation }\end{array}$ & Standard Error Mean & Variances & T & $\begin{array}{l}\text { Sig. } \\
\text { (2-tailed) }\end{array}$ \\
\hline \multirow{2}{*}{$\begin{array}{l}\text { Reading } \\
\text { Score }\end{array}$} & $\mathrm{A}$ & 64 & 20.33 & 6.999 & .875 & $\begin{array}{l}\text { Equal } \\
\text { variances } \\
\text { assumed }\end{array}$ & .663 & .509 \\
\hline
\end{tabular}

Table 2. Marks comparing between Group A and B in December, 2008

\begin{tabular}{|c|c|c|c|c|c|c|c|c|c|}
\hline \multirow{4}{*}{2008.12} & \multirow[b]{2}{*}{ Course } & \multirow[b]{2}{*}{ Group } & \multirow[b]{2}{*}{ Cases } & \multirow[b]{2}{*}{ Mean } & \multirow[b]{2}{*}{$\begin{array}{l}\text { Standard } \\
\text { Deviation }\end{array}$} & \multirow{2}{*}{$\begin{array}{l}\text { Standard } \\
\text { Error } \\
\text { Mean } \\
\end{array}$} & \multirow[b]{2}{*}{ Variances } & \multicolumn{2}{|c|}{ t-test for Equality of Means } \\
\hline & & & & & & & & $\mathrm{T}$ & $\begin{array}{r}\text { Sig. } \\
\text { (2-tailed) }\end{array}$ \\
\hline & \multirow{2}{*}{ Reading } & $\mathrm{A}$ & 64 & 70.41 & 9.742 & 1.218 & \multirow{2}{*}{$\begin{array}{l}\text { Equal } \\
\text { variances } \\
\text { assumed }\end{array}$} & \multirow[b]{2}{*}{3.951} & \multirow[b]{2}{*}{. 000} \\
\hline & & B & 62 & 63.71 & 9.360 & 1.179 & & & \\
\hline
\end{tabular}

Table 3. Results of the questionnaire in the first semester

\begin{tabular}{|l|l|l|l|}
\hline \multirow{2}{*}{ Questions } & \multicolumn{3}{l}{ Results (students number and percentage) } \\
\cline { 2 - 4 } & $\mathrm{A}$ & $\mathrm{B}$ & $\mathrm{C}$ \\
\hline Question 1 & $26(41 \%)$ & $37(58 \%)$ & $1(1 \%)$ \\
\hline Question 2 & $60(94 \%)$ & $4(6 \%)$ & 0 \\
\hline Question 3 & $24(38 \%)$ & $40(63 \%)$ & 0 \\
\hline Question 4 & $12(19 \%)$ & $47(73 \%)$ & $5(8 \%)$ \\
\hline Question 5 & $37(58 \%)$ & $27(42 \%)$ & 0 \\
\hline Question 6 & $38(59 \%)$ & $26(41 \%)$ & 0 \\
\hline Question 7 & $31(48 \%)$ & $28(44 \%)$ & $5(8 \%)$ \\
\hline Question 8 & $47(73 \%)$ & $14(22 \%)$ & $3(5 \%)$ \\
\hline
\end{tabular}

